\title{
BELEWENIS VAN PERSONE NA AAN SELFMOORD SLAGOFFERS
}

\author{
J Kinsella, M Greeff en M Poggenpoel
}

\section{VERTREKPUNT}

'n Selfmoord is die intensionele, selfgemduseerde aksie wat lei tot die dood en word deur' $n$ hoë getal persone dwarsoor die wêreld geneem. Dit is ook die derde grootste oorsaak van dood in die Westerse wêreld by persone onder die ouderdom van 20 jaar (Gangat, 1988:19).

Selfmoord het beide finansi-le en emosionele implikasies in die gemeenskap, wie direk en indirek daarvoor betaal deur middel van hoër belasting, mediese fonds- en versekeringspremies asook betalings van ongeskiktheidspensioene en rehabilitasie waar fisieke en psigiese funksionering negatief beïnvloed is na 'n onsuksesvolle selfmoordpoging (Levin, 1988:8).

Die emosionele kostes van die persone na aan selfmoordslagoffers kan nie maklik gewantifiseer word nie en is geneig om oorgesien te word (Levin, 1988:9). Vir elke persoon wat selfmoord pleeg, word tussen sewe en tien persone persoonlik geaffekteer (Lukas \& Seiden, 1987:5).

Terwyl die persone na aan individue wat 'n "normale" dood sterf, gevoelens ervaar van skok, ontkenning of hulpeloosheid, ervaar die persone na aan selfmoordslagoffers ook gevoelens van skuld, woede en emosionele wroeging, asook somatiese simptome soos uitputting, hoofpyne en hartsimptome. Hulle is ook 'n hoër risiko om self selfmoord te pleeg as die algemene populasie (Lukas \& Seiden, 1987:5). Selfmoord het dus 'n rimpeleffek op diepersone na aan selfmoordslagoffers.

Vanuit 'n persoonlike belewenis en 'n soektog in die literatuur het die navorser 'n leemte aan ondersteuning vir persone na aan selfmoordslagoffers ondervind (Kinsella, 1993:9).

Die doelstellings van die navorsing was twe-rlei van aard, naamlik:

1) om die belewenis van persone na

\section{Abstract}

The purpose of this study was to examine the experience of people close to suicide victims. Ten participants recited their experience through written essays, which was then analysed. Themes that were identified included a need for structure and ventilation of feelings, denial and avoidance behaviour, mixed feelings, a need to find meaning in the suicide, the development of empathy for other suffering people, impaired social relationships, and questions surrounding the suicide. These themes were used to develop a framework for supporting people close to suicide victims through general, sub-professional and professional measures.

aan selfmoordslagoffers te verken en te beskryf;

2) om riglyne vir ondersteuning vir persone na aan selfmoordslagoffers daar te stel om hulle strewe na heelheid te fasiliteer (Kinsella, 1993:3).

Botes (1990:3) se model vir navorsing in Verpleegkunde is gebruik om die navorsing te rig. Die Verplegingsteorie vir Mensheelheid (Oral Roberts University, Anna Vaughn School of Nursing, 1990:136-142; Randse Afrikaanse Universiteit, 1991:1-4) se metateoretiese stellings sowel as die teoretiese stellings is as vertrekpunt gebruik.

Geen ander modelle of teorie- is gebruik nie, om besoedeling van denke te voorkom. 'n Literatuur kontrole is $\mathbf{n}$ verwerking van resultate van naïewe sketse uitgevoer as betroubaarheidsmaatreël (Kinsella, 1993:5).
Die sentrale stelling wat vanuit die Verplegingsteorie vir Mensheelheid (Oral Roberts University Anna Vaughn School of Nursing, 1990:136-142) se teoretiese raamwerk vir hierdie navorsing afgelei is, is: Die persone na aan selfmoordslagoffers vereis die mobilisering van hulpbronne om hulle strewe na heelheid te bevorder. Verkenning van die belewenis van persone na aan selfmoordslagoffers stel die verpleegkundige in staat om hulpbronne te mobiliseer en sodoende die persone na aan selfmoordslagoffers se strewe na heelheid te bevorder.

\section{NAVORSINGSONTWERP EN -METODE}

Hierdie navorsing was verkennend, beskrywend van aard en kontekstueel gebonde deurdat gepoog is om nuwe insigte en begrip in te win oor die belewenis van persone na aan selfmoordslagoffers (Mouton \& Marais, 1988:12, 50-51; Bums \& Grove, 1987:81).

'n Fenomenologiese metode vir data-insameling is in hierdie navorsing gevolg (Giorgi, 1985:10). Spesiale aandag is aan betroubaarheid, geldigheid, steekproeftrekking, steekproefmetode, data-insameling en analise van data, geskenk.

\section{Betroubaarheid}

Die betroubaarheid in die navorsing is verhoog deur die volgende faktore aan te spreek (Woods \& Catanzaro, 1988:136-137):

- Die posisie van die navorser in terme van haar status posisie as persoon na aan selfmoordslagoffer en haar posisie as psigiatriese verpleegkundige;

- Keuse van deelnemers deurdat deelnemers deur middel van tussengangers volgens spesifieke kriteria vir seleksie verkry is; 
- Die sosiale konteks is gestel deurdat persone wat die werklike ervaring beleef het dat iemand na aan hulle selfmoord gepleeg het se belewenis verken en beskryf is; en

- Metodes van prosedure behels het dat daar nie meer as twee weke na die inisiële kontak verloop het nie, slegs naïwe sketse gebruik is vir data-insameling sonder opvolgonderhoude, die deelnemer in die nabye omgewing was tydens die skryf van die naijwe sketse, 'n werksprotokol aan 'n medekodeerder verskaf is en bevindinge met studies van 'n soortgelyke onderwerp vergelyk is.

\section{Geldigheid}

Beheermaatreëls wat toegepas is om geldigheid van die navorsing te verhoog (Woods \& Catanzaro, 1988:136-137), behels die volgende:

- geskiedenis en ryping van data deurdat alle naiewe sketse binne twee weke na inisiële kontak en binne een week ingesamel is, en 'n tydperk van langer as ses weke, maar minder as een jaar na die selfmoord verloop het;

- waarnemer effek deurdat die data deur middel van naïewe sketse ingesamel is terwyl die navorser in die onmiddellike omgewing gesit en boeklees het;

- keuse van deelnemers deurdat slegs persone wat voldoen het aan die seleksie kriteria deur tussengangers gevra is om aan die navorsing deel te neem.

\section{Steekproeftrekking}

Die steekproefpopulasie van hierdie navorsing het persone na aan selfmoordslagoffers in die Suid-en Noord Transvaal behels wat aan die volgende seleksie-kriteria voldoen het:

- 'n Individu na aan die persoon het selfmoord gepleeg;

- Ses weke het reeds na die selfmoord verloop, maar 'n periode van een jaar het nog nie verstryk nie;

- Die deelnemers is bereid om hulle belewenis op skrif te stel.

- Die deelnemers is tussen 21 en 65 jaar oud.

- Slegs een deelnemer per huishouding neem aan die navorsing deel.
- Die deelnemers is in staat om hulle belewenis skriftelik in Afrikaans of Engels weer te gee.

- Deelnemers is vanuit enige kultuur (Kinsella, 1993: ).

\section{Steekproefmetode}

Die deelnemers aan hierdie navorsing is bepaal deur middel van 'n doelgerigte gerieflikheids steekproef. Die deelnemers is doelgerig geselekteer deurdat elkeen 'n persoon na aan 'n selfmoordslagoffer was. Die deelnemers is verkry deur middel van tussengangers wat persone in 'n helpende hoedanigheid met selfmoordslagoffers of persone na aan selfmoordslagoffers is (Burns \& Grove, 1987:218; Abdellah \& Levine, 1965:333).

\section{Data-insameling}

Data insameling het geskied aan die hand van Giorgi (1985:10) se naïewe skets metode en daar is spesifiek gelet na die rol van die navorser, die fisieke opset en instruksies aan die deelnemers.

Die sentrale vraag "Beskryf u belewenis vanwe- die feit dat iemand na aan u selfmoord gepleeg het", was die enigste riglyne wat gegee is vir die skryf van die naiewe sketse.

\section{Data-anaiise}

Data-analise het verloop volgens 'n kombimasie van Giorgi (1985:10-19) en Kerlinger (1986:477-482) se metodes van inhoudsanalise. Die geskrewe woord is as universele raamwerk geïdentifiseer en universele kategorieë is gedefinieer. Woorde en temas is as eenhede van analise geidentifiseer en ooreenstemmende woorde en temas is in subkategorie-saam gegroepeer. Onderlinge verbande is tussen subkategorie- en kategorieë vasgestel en is volgens die aantal deelnemers gekwantifiseer en geprioritiseer. Die kodering is deur' $n$ onafhanklike mede-kodeerder gekontrolleer nadat sy 'n werksprotokol, 'n stel skoon afskrifte van die naiewe sketse en definisies van kategorieë en subkategorieë ontvang het. Konsensus van resultate is deur middel van 'n bespreking bereik en die navorser het voorts die resultate met 'n deelnemer aan die navorsing gekontrolleer.

\section{Literatuurkontrole}

Die resultate van hierdie navorsing is met soortgelyke studies in die literatuur gekontrolleer.

\section{RESULTATE EN BESPREKING VAN RESULTATE}

Tien naïewe sketse is na die inisiële kontak binne een week ingesamel. Die persone wat deelgeneem het aan die navorsing het iemand na aan hulle deur selfmoord verloor in 'n tydperk wat wissel twee tot elf maande tevore.

Bespreking van die resultate het geskied binne die eenheid van beraming en diagnose van die Verplegingsteorie vir Mensheelheid volgens die hoofkategorie interne omgewing, eksterne omgewing en kenmerkende wyses van interaksie (Oral Roberts University Anna Vaughn School of Nursing, 1990:136-142; Randse Afrikaanse Universiteit, Departement Verpleegkunde, 1991:1-4).

Vir die doel van die navorsing is aspekte wat deur vyf of meer van die deelnemers ooreenstemmend weergegee is, as verteenwoordigend beskou. Die temas en subtemas is volgens prioriteit getabuleer. (Sien tabel 1).

Individuele voorbeelde is in die bespreking gebruik om die ooreenstemmende aspekte toe te lig (Kinsella, 1993:19-24).

\section{Die kategorie Interne omgewing}

Die interne omgewing van die persone na aan selfmoordslagoffers sluit die totaliteit van prosesse in wat plaasvind in die liggaam en is liggaamlik, psigies en geestelik van aard (Randse Afrikaanse Universiteit, Departement Verpleegkunde, 1992:1).

Die mees verteenwoordigende aspekte binne die deelnemers se interne omgewings het binne die psigiese en geestelike subkategorieë plaasgevind (Kinsella, 1993: ).

\section{Die subkategorie Psige}

Die konsep psige verwys na die draer van alle belewenis en gedrag in die persone na aan selfmoordslagoffers. Dit sluit alle intellektuele, emosionele en wilsprosesse in (Randse Afrikaanse Universiteit, Departement Verpleegkunde, 1992:2).

Die belewenisse in die psige het vir die deelnemers hoofsaaklik in die intellektuele en emosionele prosesse plaasgevind (Sien tabel 1) (Kinsella, 1993:19-23).

\section{a) Intellek}

Hierdie konsep verwys na die kapasiteit vir en kwaliteit van die psigiese prosesse van dink, 
Tabel 1

Belowenis van persona na aan seltmoordslagoffers $(n=10)$

\begin{tabular}{|c|c|c|c|c|c|c|c|}
\hline \multicolumn{5}{|c|}{ Interne Omgewing } & \multicolumn{2}{|c|}{ Eksterne Omgewing } & \multirow{3}{*}{$\begin{array}{l}\text { Kenmerkende } \\
\text { myees van } \\
\text { Interakeio }\end{array}$} \\
\hline Ugoaam & \multicolumn{3}{|c|}{ Pslge } & Goes & \multirow[t]{2}{*}{ Sosiaal } & \multirow[t]{2}{*}{ Geestelik } & \\
\hline & Intellek & Emosie & WII & & & & \\
\hline $\begin{array}{ll}\text { hull } & 4 \\
\text { bewerig } & 1 \\
\text { hoofpyn } & 1\end{array}$ & 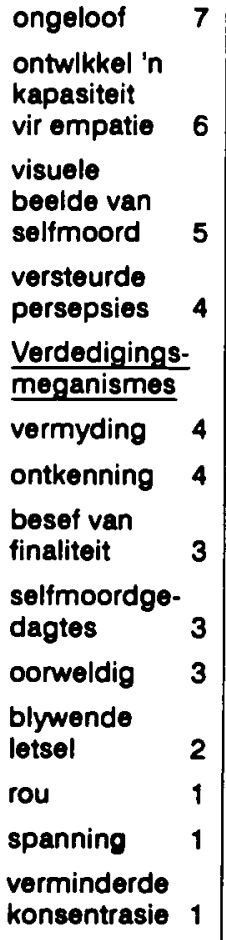 & $\begin{array}{ll}\text { woede } & 7 \\
\text { verlange } & 6 \\
\text { hartseer } & 6 \\
\text { magteloos } & 5 \\
\text { verslae } & 5 \\
\text { skok } & 6 \\
\text { skuldgevoel } & 5 \\
\text { pyn } & 4 \\
\text { wanhoop } & 4 \\
\text { depressief } & 2\end{array}$ & & $\begin{array}{l}\text { God gee } \\
\text { betekenis } \\
\text { aan die } \\
\text { selfmoord } 5 \\
\text { Troos deur die } \\
\text { maak van } \\
\text { geestellke en } \\
\text { waarde- } \\
\text { gelaaide } \\
\text { stellings } \quad 5\end{array}$ & $\begin{array}{l}\text { Behoefte om } \\
\text { met ander te } \\
\text { praat }\end{array}$ & $\begin{array}{l}\text { Moraliseer } \\
\text { oor die } \\
\text { selfmoord }\end{array}$ & $\begin{array}{l}\text { vrae rondom } \\
\text { selfmoord } 6 \\
\text { afsondering } \\
\text { van ander om } \\
\text { te treur } \\
\text { Professionele } \\
\text { behandeling } \\
\text { ontvang maar } \\
\text { dit onbe- } \\
\text { vredigend } \\
\text { gevind. } \\
\end{array}$ \\
\hline
\end{tabular}

assosiasie, analisering, oordeel en begrip waartoe die persone na aan selfmoordslagoffers in staat is (Randse Afrikaanse Universiteit, Departement Verpleegkunde, 1992:2).

Die mees verteenwoordigende aspekte wat deur die deelnemers in die intellektuele prosesse aangedui is, is die ongeloof wat hulle beleef wanneer hulle hoor van die selfmoord: "... kon ek nie glo dit is hy wat ons begrawe nie;" die kapasiteit vir empatie wat hulle ontwikkel vir ander persone wat ly: "... Jy sien die res van die familie se hartseer en wonder wat jy in jou eie groot hartseer doen om hulle pyn te verlig"; en die visuele beelde wat hulle van die selfmoord het; "..Ek sien nog die ambulans ... Ek steek my linkerhand agter haar ruggie in (wat nog warm was) en druk die ou slap liggaampie teen my bors, ek vryf die ou bleek slap handjie, ek soen haar in haar nekkie en die wangetjie ... die ambulans haar lewelose tenger liggaampie wegneem" (Kinsella, 1993:20). b) Emosie

Emosie verwys na die instrument van die persone na aan selfmoordslagoffers se voorkeure en afkeure. Emosie is 'n komplekse toestand wat ingedeel kan word in affeksie; begeerte en gevoel (Randse Afrikaanse Universiteit, Departement Verpleegkunde, 1992:2).

'n Komplekse wisseling van emosies is deur die deelnemers verteenwoordig. Woede word teenoor die selfmoordslagoffer beleef: "Hoe kon sy dit aan jou en jou familie doen", maar hulle beleef ook 'n intense verlange en hartseer: "...waar ek die donkerte van die nagte wil ingil van verlange ....". Die wete dat die deelnemers niks kan doen om die selfmoordslagoffers terug te bring nie het gevoelens van magteloosheid en verslaenheid meegebring: "Sy is weg en niemand kan daar lets aan doen nie". Skok was deur die deelnemers beleef: "Ek was so geskok dat ek heeltemal 'n 'blank' geslaan het ..." en hulle word geteister met skuldgevoelens van verskeie oorspronge: "Het ek hom in die steek gelaat?" "Kon dit nie maar liewers jy gewees het nie ..." (Kinsella, 1993:20-23).

\section{Die subkategorie Gees}

Gees verwys na daardie deel van persone na aan selfmoordslagoffers wat geskep is om in verhouding met God te staan. Die menslike gees is saamgestel deur die interverwante dele wat op 'n gekoordineerde wyse funksioneer: gewete, intuïsie en gemeenskap. Gewete is daardie deel van die menslike gees wat reg van verkeerd onderskei. Intuïsie is die gevoelsgedeelte van die gees - dit impliseer direkte kennis onafhanklik van eksterne invloed. Gemeenskap verwys na die persone na aan selfmoordslagoffers se aanbidding van God en God se kommunikasie met hulle. Gemeenskap kan ook verwys na die persone na aan selfmoordslagoffers se keuse van hulle god. Interne geestelike belewenisse sluit morele en religieuse invloede op gedrag in soos gereflekteer in waardes, etiese beginsels en die belewing van betekenis in die lewe sowel as verhouding met self. Dit reflekteer die persone na aan selfmoordslagoffers se kenmerkende wyses van interaksie met 
die omgewing (Randse Afrikaanse Universiteit, Departement Verpleegkunde, 1992:3).

Selfmoord het deur middel van hul verhouding met God vir 'n verteenwoordigende getal van die deelnemers, betekenis gekry "...maar Jesus, vandag besef ek dat 22 Junie Johan se Getsemané was ..."

Troos is ook gevind in die maak van geestelike en waardegelaaide stellings: "Die wiel van tyd draai en voort moet ons gaan tot ons pad ook ophou en wegdraai na bo".

Die kategorie Kenmerkende wyse van Interaksie.

Hierdie konsep verwys na unieke, kenmerkende interaksie-wyses tussen die interne en eksterne omgewing van die persone na aan selfmoordslagoffers. Dit impliseer beweging op die gesondheid van siekte kontinuum waarop 'n persoon se gesondheidstatus gereflekteer word. Die persone na aan selfmoordslagoffers se posisie op enige van die twee kontinuums is op enige tyd afhanklik van die interaksie tussen hulle en eksterne omgewing (Randse Afrikaanse Universiteit, Departement Verpleegkunde, 1992:6).

Verskeie vrae het vir die deelnemers rondom die selfmoord ontstaan, rondom motiewe, verklaring, hulle eie betrokkenheid en ook vrae van eksistensiële aard: "My broer was ook'n sterk mens in sy lewe, dit is hoekom ek nie kon verstaan dat by dit gedoen het nie". Uit hulle onbegrip soek hulle na bewyse wat verklarings vir hulle vrae sal gee: "Na drie maande soek ek angstig in sy woordeboek na 'n briefie ..." (Kinsella, 1993:7).

\section{INDRUKKE VAN DIE NAVORSER}

Tydens die insameling van die data wou bykans al die deelnemers nog oor die naïewe sketse of die selfmoord gesels het en moes die navorser baie beslis wees dat sy nie daaroor kan gesels nie en daarom die verwysing sisteem voorsien.

Een van die naiewe sketse was soos 'n katarsis teenoor God beskryf. Die indruk wat die navorser tydens die lees van hierdie spesifieke skets gekry het, was dat die deelnemer se onderskeid tussen Jesus en haar seun (die selfmoordslagoffer) diffuus geraak het en dat die naam van haar seun en Jesus enige tyd geruil sou kon word sonder om die konteks van die skets te verander.
Die kodering van die naïewe sketse was emosioneel uitputtend vir die navorsing en sy het baie ondersteuning van haar familie, vriende en kollegas gevra (Kinsella, 1993:23-24).

\section{LITERATUURKONTROLE}

Die literatuurkontrole wat uitgevoer is, het nie slegs die verteenwoordigende resultate van hierdie navorsing ondersteun nie, maar het ook sekere aspekte wat as nie-verteenwoordigend beskou is, so herhaaldelik vermeld, dat dit ook bespreek is. (Sien tabel 1).

\section{Belewenisse van die interne omgewing}

\section{Liggaamlike belewenisse}

Hierdie konsep sluit alle anatomiese strukture en fisiologiese prosesse van die liggaam in (Randse Afrikaanse Universiteit, Departement Verpleegkunde, 1992:1).

Vier deelnemers het as nie-verteenwoordigend liggaamlike simptome ondervind. (Sien tabel 1). Die literatuur het egter ook verskeie simptome vermeld soos styging in bloeddruk, gastro-intestinale veranderinge, hoof-en ander pyne (Barrett \& Scoth, 1911:11; Van der Wal, 1989-90; 150, 156, 157; Henley, 1984:53; Praeger \& Bermhardt, 1985:64-65).

\section{Psigiese belewenisse}

\section{a) Intellektuele belewenisse}

Alhoewel die ongeloof, ontwikkeling van empatie en visuele beelde wat deur die deelnemers verteenwoordig is deur die literatuur onderskryf is (Reed \& Greenwald, 1991:388; Van der Wal, 1989-90:158; Wertheimer, 1991:45) is sekere nie-verteenwoordigende aspekte ook vermeld.

Vermyding en ontkenning word herhaaldelik as metode om die werklikheid van die selfmoord te ontwyk, bespreek (Lukas \& Seiden, 1987:5; van der Wal, 1989-90:166; Wrobleski 1984-85:179; Henley, 1984:56 en Schuyler, 1973:316). Selfmoordgedagtes was deur drie van die deelnemers gemeld (Kinsella, 1993:20), maar verskeie skrywers vermeld dat selfmoordgedagtes voorkom by persone na aan self moordslagoffers. (Vargas, 1989:1484; Wrobleski, 1984-85:179; Van der Wal, 1989-90:157; Solomon, 1982-83:378, 384; Schuyler, 1973:313). b) Emosionele belewenisse

Die woede, verlange, skok, magteloosheid, verslaenheid en skuldgevoelens wat deur die deelnemers verteenwoordigend weergegee is (Kinsella, 1993:20) is deur die literatuur onderskryf deur verskeie skrywers (Rosenfeld \& Prupas, 1984:33-38; Reed \& Greenwald 1991:389; Wertheimer 1991:39; Barrett \& Scott, 1990:11; Lukas \& Seiden 1987:3).

\section{Geestelike belewenisse}

Die literatuurkontrole ten opsigte van vind van betekenis in die selfmoord deur in 'n verhouding met God te staan (Kinsella, 1993:30) is beide deur die literatuur bevestig en kontrasteer. Die resultate soos weergegee deur die deelnemer word bevestig deur Van der Wal (1989-90:158), Wertheimer (1991:66-67), Scott \& Barrett (1990:11), McIntosh (1985:355). Die studie van Praeger \& Bemhardt (1985:66) dui egter dat persone na aan selfmoordslagoffers deur God verraai voel en wegdraai van hulle geestelike bronne.

Belewenisse van die Eksterne Omgewing

Dit sluit daardie situasies of omstandighede buite die persone na aan selfmoordslagoffers in wat ' $n$ invloed op hulle lewens uitoefen (Randse Afrikaanse Universiteit, Departement Verpleegkunde, 1992:4).

\section{Sosiale belewenisse}

Hier word verwys na alle mense of betekenisvolle ander binne die persone na aan selfmoordslagoffers se eksterne omgewing. Sosiaal verwys ook na die organisasie strukture tussen mense en gemeenskappe. Sosiaal verwys met ander woorde na alle menslike hulpbronne (Randse Afrikaanse Universiteit, Departement Verpleegkunde, 1992:5).

Die nie-verteenwoordigende stremming wat deur die deelnemers in die navorsing weergegee is (Sien tabel 1) is herhaaldelik in die literatuur vermeld. (Praeger \& Berhardt, 1985:65; Solomon, 1982-83:378, 385; Wertheimer, 1990:108-112).

Alhoewel 'n nie-verteenwoordigende getal deelnemers 'n behoefte aan ventilasie weergegee het (Kinsella, 1993:20), is die behoefte telkemale im die literatuur bespreek (Anderson, 1991:29; Praeger \& Bemhardt, 1985:65; Wrobleski, 1984-85:177). 'n Belewing van gebrekkige ondersteuning deur die 
samelewing het ook, alhoewel nie-verteenwoordigend in die navorsing, telkemale in die literatuur voorgekom. (Calhoun, Selby \& Abemathy, 1984:259; McIntosh, 1985-86: 355-356; Henley 1984:55).

Belewenisse in kenmerkende wyses van interaksie

Die vrae wat by die deelnemers rondom die selfmoord ontstaan het, is ook onderskryf deur verskeie skrywers (Van der Wal, 1989-90:157; Lukas \& Seiden, 1987:91093, Wertheimer 1991:67; Reed \& Greenwald, 1991:388).

\section{UNIEKE ASPEKTE GEVIND IN HIERDIE NAVORSING}

Vyf deelnemers in hierdie navorsing het troos gevind in die maak van waardegelaaide stellings. (Sien tabel 2) "...ons is mense en nie 'n God nie." Dit was asof sulke stellings afstand geskep het tussen hulle en hulle emosionele pyn en dit meer draaglik gemaak het (Kinsella, 1993:31).

\section{UNIEKE ASPEKTE VANUIT DIE LITERATUUR}

Die literatuur het vermeld dat groot persentasies persone na aan selfmoordslagoffers verligting ervaar het wanneer die selfmoordslagoffer dood is. Hierdie verligting gaan gepaard daarmee dat die selfmoordslagoffer nie meer ly nie en ook dat komplikasies uit hul eie lewens verwyder is (Reed \& Greenwald, 1991:349; Van der Wal, 1989-90:157).

Geen van die deelnemers aan hierdie navorsing het verwerping weergegee nie. Die literatuur dui egter aan dat dit herhaaldelik voorkom by persone na aan selfmoordslagoffers. (Barret \& Scott, 1990:11; Reed \& Greenwald, 1991:397; Henley, 1984:59)

Geen belewenis van stigma word deur die deelnemers in hierdie navorsing weergegee nie. Alhoewel stigma dikwels in die literatuur bespreek word, blyk verskillende inligting weergegee te word. Skrywers wat die teenwoordigheid van stigma vermeld is: Wrobleski (1984-85:176), Van der Walt (1985:4, 5), Calhoun, Selby \& Abemathy (1984:259), Henley (1984:54), Barrett \& Scott (1990:11), Goldney (1987:141). Die navorsing uitgevoer deur Solomon (1982-83:381) vind egter teenstellende resultate en Van der Wal (1989-90:161) wys daarop dat alhoewel daar dikwels na stigma in die literatuur verwys word, daar geen detail in informasie gegee word nie.

\section{GEVOLGTREKKINGS}

Vanuit die vergelyking van die resultate van hierdie navorsing en die literatuur, het dit geblyk dat die belewenis van persone na aan selfmoordslagoffers baie intens is, met komplekse emosies en reaksies wat hulle strewe na heelheid beïnvloed.

Hulle lewens word in een oomblik in chaos omskep wanneer hulle van die selfmoord hoor. Dit is asof hulle nie kan of wil glo wat met hulle gebeur nie en die komplikasie van 'n verlengde rou vind plaas wanneer hulle bly ontken en vermy. Gedagtes bly egter maal om die selfmoord of selfmoordslagoffer en dikwels ontwikkel hulle versteurde persepsies. Hulle het dus'n behoefte aan struktuur, ondersteuning en ventilasie van hulle belewenis.

Daar ontstaan baie vrae rondom die selfmoord wat weer verskillende gevoelens ontlok, waarvan woede, verligting en skuldgevoelens die rouproses kan kompliseer. Die wete dat hulle niks kan doen om die situasie te verander nie lei tot 'n gevoel van magteloosheid, maar dit is asof hulle betekenis in die selfmoord vind vanuit 'n verhouding met God en waardegelaaide stellings. Hulle het dus die behoefte om die selfmoord meer sinvol te maak.

Die persone na aan selfmoord bly egter nie net betrokke by hulle eie belewenis nie, maar dit is asof bulle 'n kapasiteit ontwikkel om meer empaties teenoor ander te kan staan. Dit kan dus as terapeutiese hulpbron mobiliseer word (Kinsella, 1993: ).

Sekere temas het uit die belewenis van die persone na aan selfmoordslagoffers na vore getree. Hierdie temas kan gebruik word om hulle strewe na heelheid te fasiliteer.

Temas wat vanuit die gevolgtrekkinge ge5dentifiseer kan word is, naamlik:

\section{TEMAS BINNE DIE INTERNE OMGEWING.}

Temas geïdentifiseer binne die interne omgewing kom hoofsaaklik in die intellektuele, emosionele en geestelike belewenisse voor. Sien tabel 2 vir toeligting van hierdie besprekingspunt.

\section{TEMAS BINNE DIE EKSTERNE OMGEWING.}

Temas wat in die eksterne omgewing geïdentifiseer is, vind binne die sosiale belewenis plaas. Sien tabel 3 vir toeligting van hierdie besprekingspunt.
TERMAS BINNE DIE KENMERKENDE WYSES VAN INTERAKSIE.

Sien tabel 4 vir toeligting van hierdie besprekingspunt.

\section{TEKORTKOMINGE VAN DIE NAVORSING}

- Die mees beperkende faktor van die navorsing was die klein aantal deeinemers.

- Opvolgonderhoude en veldnotas sou die belewenis van die deelnemers kon verdiep (Kinsella, 1993: ).

\section{TOEPASSINGSMOONTLIKHEDE}

Die toepassingsmoontlikhede van die navorsing kom na vore in die verpleegkundige onderrigverpleegkundige navorsings- en verpleegkundige praktyk areas.

\section{In verpleegkundige onderrig}

Psigiatriese verpleegkundiges, klimiese verpleegspesialiste, nie-professionele vrywilligers en ander lede van die multi-professionele span dra almal by tot die fasilitering van geestesgesondheid by die individue, die gesin en gemeenskap. Deur middel van onderrig word hierdie hulpgewers in 'n posisie geplaas waar hulle hierdie strewe na heelheid kan fasiliteer.

Deur die spesifieke temas wat in hierdie navorsing by die persone na aan selfmoordslagoffers geidentifiseer is, kan 'n gestruktureerde onderrigprogram aangebied word en ingesluit word in die kurrikulum van voor- en nagraadse psigiatriese verpleegkunde studente. So 'n onderrigprogram kan ook ander hulpgewers in staat stel om die persone na aan selfmoordslagoffers se strewe na heelheid effektief te fasiliteer (Kinsella, 1993:).

\section{In verpleegkundige navorsing}

Vanuit die resultate van hierdie navorsing het verdere toepassingsmoontlikhede ontstaan. Verdere navorsing oor die werklike bestaan van stigma kan getoets word omdat die vraag ontstaan of stigma om selfmoord wel bestaan en of dit 'n subjektiewe belewenis is.

Die waardesisteem van die samelewing het in hierdie navorsing ' $n$ rol gespeel om stabiliteit te verleen aan die persone na aan selfmoordslag offers. Die deelnemers van die navorsing was almal Afrikaanssprekend en vanuit spesifieke 
Tabel 2

Geĩdenthiseerde temas binne interne omgewing

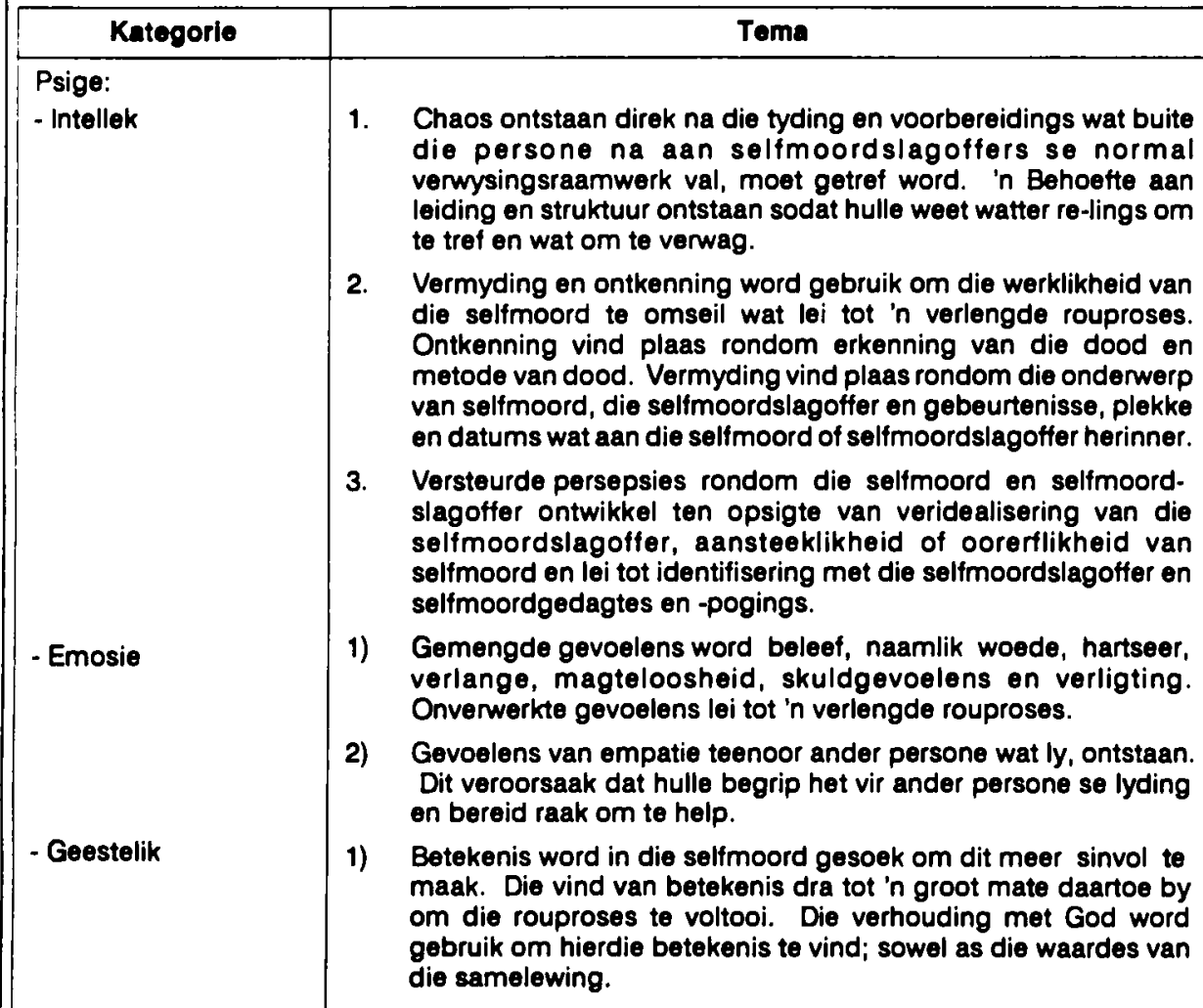

Tabel 3

Gaidentiflecerde temas in dle aksterne omgowing

\begin{tabular}{|l|ll|}
\hline Kntegorie & \multicolumn{1}{|c|}{ Tema } \\
\hline Sosiaal: & 1. $\begin{array}{l}\text { Verhoudings word gestrem deurdat die samelewing persone na } \\
\text { aan selfmoord slagoffers vermy omdat hulle Persoonllke } \\
\text { verhoudings raak oorbetrokke of onbetrokke en veroorsaak konflik. }\end{array}$ \\
& 2. $\begin{array}{l}\text { 'n Behoefte aan ventilering oor hulle belewenis ontstaan. in } \\
\text { Onvermoë om te verklaar verleng die rouproses. }\end{array}$ \\
\hline
\end{tabular}

\section{Tabol 4}

Goidentifiseorde temes blnne die kenmerkende wyees van intareksie

\section{Toma}

Vrae ontstaan rondom die selfmoord wat eksistensie-l van aard is, maar ook vrae rondom die motiewe van die selfmoordslagoffers, hulle uiteinde na die dood en hulle eie aandeel aan die selfmoord.

geografiese areas. Navorsing oor die waardesisteme van verskillende samelewings se bydrae tot die belewenis van persone na aan selfmoordslagoffers kan dus nagevors word.

Persone se belewenis oor wanneer die rouproses afgehandel is, kan nagevors word. Sommige van die reaksies van die deelnemers a an hierdie navorsing veroorsaak 'n verlengde of gefikseerde rouproses. Dit is egter onduidelik wanneer die rouproses as afgehandel beskou word. 'n Studie oor die belewenis van ondersteuning deur persone na aan selfmoordslagoffers wat ondersteuningsprogramme gevolg het en wat nie 'n ondersteuningsprogram gevolg het nie, kan gedoen word om die waarde van ondersteuningsprogramme te evalueer (Kinsella, 1993: ).

\section{In verpleegkundige praktyk}

Deur kennis van die belewenis van persone na aan selfmoordslagoffers kan die psigiatriese verpleegkundige hierdie persone se strewe na heelheid fasiliteer.
Die opgestelde riglyne vir ondersteuning van persone na aan selfmoordslagoffers kan behulpsaam wees en 'n meer doelgerigte fasilitering. Aandag word aan die interne en eksterne omgewings sowel as die kenmerkende wyses van interaksie gebied om die heelheid van die persone te akkommodeer (Kinsella, 1993).

Riglyne vir ondersteuning van persone na aan selfmoordslagoffer.

Drie fases van ondersteuning word aanbeveel. In die eerste fase word ondersteuning gebied om na die behoeftes van die selfmoordslagoffers direk na die selfmoord om te sien. Die tweede fase word daarop gemik om die persone na aan selfmoordslagoffers van hulp te wees om die realiteit van die selfmoord te integreer. In die derde fase word gepoog om persone wat in 'n verlengde rouproses is, van hulp te wees om die rouproses af te sluit.

Ondersteuning kan deurlopend deur middel van die aanbied van algemene inligting, nie-professionele ondersteuning en professionele ondersteuning geskied (Kinsella, 1993: ).

Die riglyne sal uiteengesit word in die artikel: "Riglyne vir ondersteuning van persone na aan selfmoordslagoffers".

\section{SAMEVATTING}

In die voorafgaande navorsing is die belewenis van persone na aan selfmoordslagoffers verken en beskryf.

Vanuit die analise van die persone na aan selfmoordslagoffers se belewenis in hul interne omgewing, eksterne omgewing en kenmerkende wyses van interaksie, is sekere gevolgtrekkings gemaak. Sekere temas is geidentifiseer wat as vertrekpunt kan dien om riglyne ter ondersteuning van persone na aan selfmoordslagoffers daar te stel.

\section{BIBLIOGRAFIE}

ABDELLAH, FG \& LEVINE, E (1979): Better patient care through nursing research, second edition. New York. MacMillan Publishing Company.

BARRET, TW \& SCOTT, TB (1990): Suicide bereavement and recovery patterns compared with nonsuicide bereavement patterns. Suicide and Life Threatening Behaviour, 20(1), Spring 1990:1-15.

ANDERSON, DB (1991): Never too late: Resolving the grief of suicide. 
Joumal of Psychosocial Nursing, 29(S), 1991:29-31.

BOTES, A (1990): Teorievorming in die Verpleegkunde (Kern aantekeninge). Johannesburg: Randse Afrikaanse Universiteit.

BURNS, N \& GROVE, SK (1987): The practice of Nursing Research. Philadelphia, PA: WB Saunders Company.

CALHOUN, LG SELBY, JW \& ABERNATHY, CB (1984): Suicidal Death: sociatal reactions to bereaved survivors. The Joumal of Psychology, Vol 116, 1984:255-261.

GANGAT, AE (1988): Suicide in South Africa - a general overview and research findings. (In: Schlebusch, eds. 1988: Suicidal Behaviour. Durban: University of Natal 18-26.)

GIORGI A ed (1985): Phenomenology and Psychological Research. Pittsburgh: Duguesne University Press.

GOLDNEY, RD SPENCE, ND \& MOFFIT, PF (1987 April): The aftermatch of Suicide. Journal of Community Psychology, Vol. 15: 141-148.

HENLEY, SHA (1984 Summer): Bereavement following suicide. Current Psychological Research and Reviews, 1984:53-61.

KERLINGER, FN (1986): Foundations of Behavioural Research, 3rd ed. Chicago: Holt, Rinehart and Winston, Inc.

KINSELLA, J (1993): Belewenis van persone na aan selfmoordslagoffers. Johannesburg Randse Afrikaanse Universiteit. (Ongepubliseerde verhandeling $M$-Curationus).

LEVIN, A (1988): The costs of Suicide. (In: Schlebusch, L eds. 1988. Suicidal Behaviour Durban: University of Natal, 6-17).
LEVIN, A (1992): Suicide patterns and trends in South Africa's population groups. (In: Schlebusch, L eds Suicidal Behaviour 2. Durban: University of Natal, 5-8).

LUKAS, C \& SEIDEN, HM (1987): Silent grief: Living in the wake of suicide. London: Papermore.

McINTOSH, JL (1985-86): Survivors of suicide. Omega, 16(4), 1985-86: 355-357.

MOUTON, J \& MARAIS, HC (1988): Metodologie van die geesteswetenskappe. Pretoria: Raad vir Geesteswetenskaplike Navorsing.

ORAL ROBERTS UNIVERSITY ANNA VAUGHN SCHOOL OF NURSING (1991): Die Verplegingsteorie vir Mensheelheid. Vertaal deur die Randse Afrikaanse Universiteit. Johannesburg: Randse Afrikaanse Universiteit.

PRAEGER, SG \& BERNHARDT, GR (1985): Survivors of Suicide. Family and Community Health, November 1985:62-71.

REED, MD \& GREENWALD, JY (1991): Survivor-victim status, attachment, and sudden death bereavement. Suicide and Life Threatening Behaviour, 21(4), Winter 1991:385-401.

ROSENFELD, L \& PRUPAS, M (1984): Left alive: After a suicide death in the family. Springfield: Charles C. Thomas.

SOLOMON, MI (1982-83): The bereaved and the Stigma of Suicide. Omega. 13(4), 1982-83: 377-386.

VAN DER WAL, J (1989-90): The aftermath of suicide: $A$ review of empirical evidence. Omega. Vol 20(2), 149-171.

VAN DER WALT, M (1988 January): Die naspel van 'n selfmoord. Word and Action, 4-5.
VARGAS, LA, LOYA, F \& HODDE-VARGAS， J (1989 November): Exploring the multidimensional aspects of Grief reactions. American Journal of Psychiatry, 146(11) : 1484-1488.

WERTHEIMER, A (1991): A special scar: The experiences of people bereaved by Suicide. London: Routledge.

WOODS, NF \& CATANZARO, M (1988): Nursing Research, theory and practice. St. Louis: CV Mosby Company.

WROBLESKI, A (1984-85): The suicide survivors grief group. Omega, 15(2): 173-185. 